\title{
STATISTIČKA OBRADA PODATAKA 0 VREMENSKIM NEPRILIKAMA U SVRHU ODREĐIVANJA MJESEČNOG INTERVALA S MATEMATIČKI OČEKIVANIM DANIMA ZASTOJA PRI RADU GRADILIŠTA NA PODRUČJU GRADA RIJEKE
}

\author{
STATISTICAL DATA ANALYSIS OF WEATHER \\ CONDITIONS AIMING AT DETERMINING THE \\ MATHEMATICAL EXPECTATION OF \\ CONSTRUCTION SITE DELAYS IN RIJEKA WITHIN A \\ MONTHLY PERIOD
}

\author{
Martina Šopić*, Diana Car-Pušić*
}

\begin{abstract}
Sažetak
Meteorološki i klimatski uvjeti mogu uvelike utjecati na kontinuirani i zadovoljavajući tijek izvođenja radova na gradilištu. Posebno je važno, ali nedovoljno primijenjeno u praksi, prilikom izrade vremenskog plana i definiranja roka za građenje uzeti u obzir i moguće zastoje pri radu gradilišta zbog nepovoljnih vremenskih uvjeta. Meteorološki i klimatski uvjeti imaju različit utjecaj ovisno o lokaciji gradilišta. Iz tog razloga, kako bi se statistički obradio utjecaj vremenskih neprilika na području grada Rijeke, s pripadajućom umjereno toplom, vlažnom klimom i vrućim ljetima (Cfa Köppen-ova klasifikacija klime), od Državnog hidrometeorološkog zavoda (DHMZ) zatraženi su meteorološki podaci o vremenskim neprilikama za vremensko razdoblje od 25 godina, izmjerenih i zabilježenih u glavnoj meteorološkoj postaji u gradu Rijeci. Vremenske neprilike za koje su zatraženi podaci, a koje su karakteristične za klimatsko područje grada Rijeke, su Oborine ( $\geq 10 \mathrm{~mm}$ ), Olujni vjetar, Hladni dani $\left(T_{\min }<0{ }^{\circ} \mathrm{C}\right)$ i Vrući dani $\left(T_{\max } \geq 30{ }^{\circ} \mathrm{C}\right)$. Zatraženi meteorološki podaci su u obliku ukupnog broja dana u mjesecu sa zabilježenim djelovanjem pojedine vremenske neprilike. Ciljevi ovog rada su, primjenom odgovarajućih statističkih testova,
\end{abstract}

\footnotetext{
*Sveučilište u Rijeci, Građevinski fakultet, Radmile Matejčić 3, 51000 Rijeka E-mail: \{martina.sopic,diana.car.pusic\}@gradri.uniri.hr
} 
testiranje različitosti na razini značajnosti od $5 \%$, među skupinama vremenskih neprilika (Kruskal-Wallis test, Mann-Whitney test) te, zatim, određivanje $95 \%$ pouzdanog intervala s matematički očekivanim danima zastoja pri radu gradilišta za svaki mjesec pojedinačno (intervalna procjena očekivanja u skupini s normalnom distribucijom podataka). Mjesečni intervali dobiveni statističkom obradom $s$ matematički očekivanim danima zastoja, zbog vremenskih neprilika predstavljaju vrijedan ulazni parametar u svrhu preciznije izrade vremenskog plana i definiranja roka za građenje na području grada Rijeke.

Ključne riječi: vremenske neprilike, meteorološki podaci, statistička obrada, zastoji, gradilište, vremenski plan, Rijeka

\begin{abstract}
Meteorological and climate conditions can significantly affect the continuous and satisfactory progress of work on a construction site. When it comes to creating schedules and defining deadlines at a construction site it is very important to consider possible time delays during work execution as a result of adverse weather conditions. Still, this practice isn't widely applied. Weather and climate conditions may have different effects depending on the location of the construction site. Hence, to be able to statistically analyze the effect of weather conditions in Rijeka area, with it's moderately warm and humid climate with hot summers (Cfa - Köppen climate classification), data on weather conditions that were measured and recorded in the central meteorological station in Rijeka during the period of last 25 years were requested from the Croatian Meteorological and Hydrological Service (DHMZ). The weather conditions the data was requested on are specific to the microclimate of the Rijeka area. They are as follows: precipitation $\left(\geq 10 \mathrm{~mm}\right.$ ), storm winds, cold days ( $T_{\mathrm{min}}$ $<0{ }^{\circ} \mathrm{C}$ ) and hot days $\left(\mathrm{T}_{\max } \geq 30^{\circ} \mathrm{C}\right)$. Requested meteorological data are in the form of the total number of days in a month with specific weather conditions recorded. The aim of this paper is to apply appropriate statistical tests in order to examine variations on the scale of significance of $5 \%$ between distinct weather conditions (Kruskal-Wallis test, Mann-Whitney test), and to determine the 95\% reliable interval of the mathematical expectation of work delays on a construction site for each month (an interval expectations assessment within a group containing normal data distribution). Monthly intervals obtained via statistical analysis that include mathematical expectation of execution delays due to poor weather condition represent a valuable input parameter for the purpose of creating a more precise schedule and defining construction deadlines in the Rijeka area.
\end{abstract}

Keywords: weather conditions, meteorological data, statistical analysis, delays, deadlines, schedules, Rijeka 


\section{Uvod}

Meteorološki i klimatski uvjeti mogu uvelike utjecati na kontinuirani i zadovoljavajući tijek izvođenja radova na gradilištu. Vremenske neprilike tako utječu na smanjenje produktivnosti na gradilištu, kašenjenje projekta, prekoračenje troškova i pojavu ugovornih (pri)tužbi [1]. Zanemarivanje klimatskog utjecaja i analize utjecaja klime na fond radnog vremena jedan je od ključnih čimbenika za održavanje vremenskog roka i proračuna [2]. Kvantificiranje vremenskog utjecaja na izvođenje radova na gradilištu predstavlja vrijedan ulazni parametar pri izradi vremenskog plana za građenje, procjeni troškova i davanju ponude za izvođenje radova [3]. Stoga je posebno važno, ali nedovoljno primijenjeno u praksi, prilikom izrade vremenskog plana i definiranja roka za građenje uzeti u obzir i procjenu zastoja pri radu gradilišta zbog nepovoljnih vremenskih uvjeta na temelju matematičke i statističke obrade dostupnih podataka.

Meteorološki i klimatski uvjeti imaju različit utjecaj ovisno o lokaciji gradilišta. Iz tog razloga, kako bi se statistički obradio utjecaj vremenskih neprilika na području grada Rijeke s pripadajućom umjereno toplom, vlažnom klimom i vrućim ljetima (Cfa - Köppen-ova klasifikacija klime), od Državnog hidrometeorološkog zavoda (DHMZ) zatraženi su meteorološki podaci o vremenskim neprilikama za vremensko razdoblje od 25 godina, izmjereni i zabilježeni u glavnoj meteorološkoj postaji u gradu Rijeci. Vremenske neprilike za koje su zatraženi podaci, karakteristične za klimatsko područje grada Rijeke, su Oborine $(\geq 10 \mathrm{~mm})$, Olujni vjetar, Hladni dani $\left(\mathrm{T}_{\min }<0{ }^{\circ} \mathrm{C}\right)$ i Vrući dani $\left(\mathrm{T}_{\max } \geq 30^{\circ} \mathrm{C}\right)$. Zatraženi meteorološki podaci su u obliku ukupnog broja dana u mjesecu sa zabilježenim djelovanjem pojedine vremenske neprilike.

Ciljevi ovog rada su, primjenom odgovarajućih statističkih testova, testiranje različitosti na razini značajnosti od $5 \%$, među skupinama vremenskih neprilika (Kruskal-Wallis test, Mann-Whitney test) te, zatim, određivanje $95 \%$ pouzdanog intervala s matematički očekivanim danima zastoja pri radu gradilišta za svaki mjesec pojedinačno (intervalna procjena očekivanja u skupini s normalnom distribucijom podataka). Mjesečni intervali dobiveni statističkom obradom s matematički očekivanim danima zastoja, zbog vremenskih neprilika predstavljaju vrijedne ulazne parametre u svrhu preciznije izrade vremenskog plana i definiranja roka za građenje na području grada Rijeke. 


\section{Statistički testovi}

\subsection{Kruskal-Wallis i Mann-Whitney}

Kruskal-Wallis (H test) je neparametrijski test koji omogućuje međusobnu usporedbu tri ili više nezavisnih skupina podataka s podacima koji po svojoj prirodi imaju ordinalnu skalu. Neparametrijske testove koristimo u slučajevima kada imamo podatke koji se ne distribuiraju normalno, kao i u nekim drugim specifičnim slučajevima kada nisu zadovoljeni svi (pred)uvjeti za korištenje odgovarajućeg parametrijskog testa. Parametrijski testovi imaju veću snagu od neparametrijskih testova. Međutim, značajno gube na snazi ako su pretpostavke o opravdanosti korištenja parametrijskih testova netočne. Veća snaga testa predstavlja vjerodostojniju obradu podataka i manju mogućnost statističkih pogrešaka.

Ordinalna skala izražava mogućnost određenog redoslijeda ili poretka među podacima. Pri obradi podataka na ordinalnoj skali može se koristiti rangiranje podataka. Rangiranje podataka je postupak pri kojem podatke svih skupina poredamo po veličini, od najmanje vrijednosti prema najvećoj. Pritom, svakom podatku dodijelimo odgovarajuću vrijednost ranga počevši od vrijednosti 1 (rang za podatak koji ima najmanju vrijednost, prethodnog poretka podataka po veličini), zatim rang vrijednosti 2 za sljedeći podatak, sve do ranga vrijednosti $n$ (za podatak s najvećom vrijednosti). Ako imamo više podataka iste vrijednosti, dodijelimo im aritmetičku sredinu rangova koje bi dobili da imamo podatke različitih vrijednosti.

Testna statistika $(H)$ Kruskal-Wallis-ovog testa je (1), pri čemu je $k$ broj nezavisnih skupina s brojem podataka $n_{i}(i=1,2, \ldots k), R_{i}$, je suma rangova $i$-te skupine $(i=1,2, \ldots k)$, a $n$ je ukupan broj podataka svih skupina $(n=$ $\left.n_{1}+n_{2}+\cdots+n_{k}\right)[4]$.

$$
H=\frac{12}{n(n+1)} \sum_{i=1}^{k} \frac{R_{i}^{2}}{n_{i}}-3(n+1)
$$

Nulta hipoteza $H_{0}$ je pretpostavka istinitosti suda da sve skupine imaju distribuciju istog oblika. Testna statistika $(H)$ ima aproksimativno distribuciju (2) s $(k-1)$ stupnjeva slobode (df) te pretpostavlja da su skupine nezavisne, da imaju distribuciju istog oblika te da svaka skupina ima minimalno pet podataka, $n_{i} \geq 5$ [4].

$$
H \sim \chi^{2}
$$

Za razinu značajnosti $\alpha$, kritično područje testa je oblika (3), gdje je $\chi_{\alpha}^{2}$ kvantil $\chi^{2}$ distribucije $\mathrm{s}(k-1)$ stupnjeva slobode (df) ovisno o razini značajnosti $\alpha[4,5]$.

$$
\left[\chi_{\alpha}^{2} s(k-1) \text { stupnjeva slobode }(d f), \infty\right\rangle
$$


Nultu hipotezu odbacujemo ako je (4), gdje je $\chi_{\alpha}^{2}$ kvantil $\chi^{2}$ distribucije $s$ $(\mathrm{k}-1)$ stupnjeva slobode (df) ovisno o razini značajnosti $\alpha[4,5]$.

$$
H>\chi_{\alpha}^{2}
$$

Vrijednost testne statistike $(H)$ možemo iščitati provođenjem KruskalWallisov-og testa u Real Statistics-u (H-ties), odnosno, ovisno o zadanoj razini značajnosti $\alpha$, nultu hipotezu odbacujemo ako je (5), pri čemu je vrijednost $p$ najveća razina značajnosti za koju ne odbacujemo nultu hipotezu. Real Statistics je dodatak u Excel-u s naprednim mogućnostima obrade podataka u svrhu jednostavnije primjene širokog spektra statističkih analiza.

$$
p<\alpha
$$

Neparametrijski Kruskal-Wallis-ov test, dakle, koristimo u slučajevima kada imamo tri ili više nezavisnih skupina podataka s podacima koji nemaju normalnu distribuciju, kao i u slučajevima kada su varijance među skupinama jako različite ili su prisutne ekstremno odstupajuće vrijednosti (outlieri) [6]. Primjenom Kruskal Wallis-ovog testa možemo zaključiti postojanje razlika među testiranim skupinama podataka, ali ne možemo znati koje se točno skupine razlikuju. U tu svrhu, potrebno je provesti post hoc analizu koristeći Mann-Whitney-jev test, međusobno uspoređujući svake dvije skupine. Pritom, važno je smanjiti razinu značajnosti da bi smanjili mogućnost pogreške prve vrste. Pogreška prve vrste je odbacivanje nulte hipoteze, iako je istinita. Moguće korekcije su [6]: Bonferroni-jeva (6) i Dunn-Šidákova (7), gdje je $m$ broj hipoteza koje testiramo.

$$
\begin{aligned}
& \alpha^{\prime}=\frac{\alpha}{m} \\
& \alpha^{\prime}=1-(1-\alpha)^{\frac{1}{m}}
\end{aligned}
$$

Mann-Whitney-jev (U test) je neparametrijski test za međusobnu usporedbu dviju nezavisnih skupina podataka s podacima koji po svojoj prirodi imaju ordinalnu skalu.

Testna statistika ( $U$ ) Mann-Whitney-jevog testa je (8), pri čemu je $R_{1}$ suma rangova prve skupine, $R_{2}$ suma rangova druge skupine, $n_{1}$ ukupan broj podataka prve skupine, a $n_{2}$ ukupan broj podataka druge skupine [4].

$$
\begin{aligned}
& U=\min \left\{U_{1}, U_{2}\right\} \\
& U_{1}=n_{1} n_{2}+\frac{n_{1}\left(n_{1}+1\right)}{2}-R_{1} \\
& U_{2}=n_{1} n_{2}+\frac{n_{2}\left(n_{2}+1\right)}{2}-R_{2}
\end{aligned}
$$


Nulta hipoteza $H_{0}$ je pretpostavka istinitosti suda da dvije skupine imaju distribuciju istog oblika. Testiramo postoji li statistički značajna razlika između medijana dviju ispitivanih skupina. Nultu hipotezu $H_{0}$ odbacujemo ako je (9), gdje je $U_{c r i t}$ kritična vrijednost na razini značajnosti $\alpha$. Kritičnu vrijednost $\left(U_{\text {crit }}\right)$ možemo iščitati provedbom Mann-Whitney testa u Real Statistics-u, odnosno nultu hipotezu možemo odbaciti ako je vrijednost $\mathrm{p}$ manja od razine značajnosti $\alpha$ (5). Za velike uzorke ( $n>30$, ali u praksi se češće uzima $n>40$ ), testna statistika $(U)$ ima normalnu distribuciju pa kritičnu vrijednost $\left(U_{\text {crit }}\right)$ možemo tražiti među kvantilima normalne distribucije [6, 7]

$$
U<U_{\text {crit }}
$$

Ako primjenom Kruskal-Wallis-ovog testa zaključimo da nema značajnih razlika među skupinama, nije potrebno provoditi Mann-Whitneyjev test.

\subsubsection{Primjena Kruskal-Wallis i Mann-Whitney testova}

Karakteristika mjeseca od listopada do travnja za vremensko razdobolje od 25 godina na području grada Rijeke ogleda se u tome da za vremensko razdoblje od 25 godina (od 1992. do 2016. g.) nije zabilježen niti jedan vrući dan $\left(\mathrm{T}_{\max } \geq 30^{\circ} \mathrm{C}\right)$, dok se karakteristika mjeseca od svibnja do rujna ogleda $\mathrm{u}$ tome da za isto vremensko razdoblje nije zabilježen niti jedan hladni dan $\left(\mathrm{T}_{\min }<0{ }^{\circ} \mathrm{C}\right.$ ) (prema podacima iz DHMZ-a). Sukladno navedenom, svaki pojedini mjesec ima tri karakteristične skupine vremenskih neprilika. Tako je u mjesecima od listopada do travnja zabilježeno djelovanje Oborina $(\geq 10$ $\mathrm{mm}$ ), Olujnog vjetra i Hladnih dana $\left(\mathrm{T}_{\min }<0{ }^{\circ} \mathrm{C}\right)$, dok je za mjesece od svibnja do rujna zabilježeno djelovanje Oborina ( $\geq 10 \mathrm{~mm}$ ), Olujnog vjetra i Vrućih dana $\left(\mathrm{T}_{\max } \geq 30{ }^{\circ} \mathrm{C}\right)$. Vremenski uvjeti ne uključuju postojanje jasnih međusobnih korelacija prilikom njihovih pojava [1]. Time vremenske neprilike predstavlju nezavisne skupine jer svaka pojedina vremenska neprilika nije nužno i uvjet pojave neke druge vremenske neprilike.

U Tablici 1. prikazan je pregled broja dana sa zabilježenim djelovanjem pojedine vremenske neprilike za mjesec siječanj za vremensko razdoblje od 25 godina (od 1992. do 2016. g) na području grada Rijeke. 
M. Šopić, D. Car-Pušić • Statistička obrada podataka o vremenskim neprilikama u svrhu.. 73

Tablica 1. Pregled broja dana sa zabilježenim djelovanjem vremenskih neprilika za mjesec siječanj

\begin{tabular}{|c|c|c|c|c|}
\hline \multirow{2}{*}{$\frac{\text { Rijeka }}{\text { Siječanj }}$} & \multicolumn{4}{|c|}{ Pregled broja dana } \\
\hline & $\begin{array}{c}\text { Oborine } \geq 10 \\
\mathrm{~mm}\end{array}$ & Olujni vjetar & $\begin{array}{l}\text { Hladni dani } \\
\mathrm{T}_{\min }<0{ }^{\circ} \mathrm{C}\end{array}$ & $\begin{array}{l}\text { Vrući dani } \\
\mathrm{T}_{\max } \geq 30^{\circ} \mathrm{C}\end{array}$ \\
\hline 1992. & 1 & 1 & 6 & 0 \\
\hline 1993. & 0 & 3 & 8 & 0 \\
\hline 1994. & 4 & 1 & 1 & 0 \\
\hline 1995. & 6 & 3 & 9 & 0 \\
\hline 1996. & 5 & 1 & 6 & 0 \\
\hline 1997. & 8 & 1 & 0 & 0 \\
\hline 1998. & 2 & 4 & 5 & 0 \\
\hline 1999. & 4 & 2 & 2 & 0 \\
\hline 2000. & 0 & 1 & 9 & 0 \\
\hline 2001. & 7 & 5 & 4 & 0 \\
\hline 2002. & 1 & 1 & 8 & 0 \\
\hline 2003. & 4 & 7 & 8 & 0 \\
\hline 2004. & 5 & 3 & 10 & 0 \\
\hline 2005. & 1 & 7 & 7 & 0 \\
\hline 2006. & 3 & 3 & 10 & 0 \\
\hline 2007. & 5 & 1 & 1 & 0 \\
\hline 2008. & 6 & 0 & 1 & 0 \\
\hline 2009. & 7 & 1 & 9 & 0 \\
\hline 2010. & 8 & 0 & 8 & 0 \\
\hline 2011. & 2 & 4 & 5 & 0 \\
\hline 2012. & 2 & 0 & 8 & 0 \\
\hline 2013. & 6 & 3 & 2 & 0 \\
\hline 2014. & 8 & 2 & 1 & 0 \\
\hline 2015. & 4 & 1 & 1 & 0 \\
\hline 2016. & 6 & 1 & 6 & 0 \\
\hline UKUPNO & 105 & 56 & 135 & 0 \\
\hline
\end{tabular}

Shapiro Wilk test je test koji provjerava slijede li podaci normalnu distribuciju. U dodatku Excela, Real Statistics-u, ovisno o definiranoj razini značajnosti $\alpha$, informacija o normalnoj distribuciji podataka je u obliku potvrde ili negacije „normalnosti“ podataka (normal: yes/no). Testiramo distribucije podataka pojedinih nezavisnih skupina vremenskih neprilika, primjenom Shapiro-Wilk testa u Real Statistics-u na razini značajnosti od 5 $\%(\alpha=0,05)$, a za mjesec siječanj. Razina značajnosti od $5 \%$ znači da za 5 $\%$ slučajeva imamo pogrešku prve vrste, odnosno da za $5 \%$ slučajeva 
odbacujemo nultu hipotezu, iako je istinita. Provođenjem Shapiro-Wilk testa za svaku pojedinu skupinu dobivamo rezultate da nije zadovoljen uvjet normalne distribucije podataka svih skupina vremenskih neprilika (Tablice 2.-4.). S obzirom na ukupan broj podataka u svakoj skupini i rezultatima da sve skupine nemaju normalnu distribuciju podataka, možemo zaključiti da je prikladno koristiti neparametrijski Kruskal-Wallis-ov test kako bi testirali postoje li statistički značajne razlike među skupinama vremenskih neprilika.

Tablica 2. Primjena Shapiro-Wilk testa u Real Statistics-u za mjesec siječanj za Oborine $(\geq 10 \mathrm{~mm})$

Shapiro-Wilk Test

\begin{tabular}{lr} 
& Oborine $\geq 10 \mathrm{~mm}$ \\
\hline W-stat & 0,939668981 \\
p-value & 0,145446539 \\
alpha & 0,05 \\
normal & yes \\
\hline
\end{tabular}

Tablica 3. Primjena Shapiro-Wilk testa u Real Statistics-u za mjesec siječanj za Olujni vjetar

Shapiro-Wilk Test

\begin{tabular}{lr} 
& Olujni vjetar \\
\hline W-stat & 0,847414836 \\
p-value & 0,001573667 \\
alpha & 0,05 \\
normal & no \\
\hline
\end{tabular}

Tablica 4. Primjena Shapiro-Wilk testa u Real Statistics-u za mjesec siječanj za Hladne dane $\left(T_{\min }<0{ }^{\circ} \mathrm{C}\right)$

Shapiro-Wilk Test

\begin{tabular}{lr} 
& Hladni dani Tmin $<0{ }^{\circ} \mathrm{C}$ \\
\hline W-stat & 0,890471223 \\
p-value & 0,011446066 \\
alpha & 0,05 \\
normal & no \\
\hline
\end{tabular}

Prije primjene Kruskal-Wallis-ovog testa postavljamo nultu hipotezu da sve skupine vremenskih neprilika imaju distribuciju istog oblika (10). Alternativna hipoteza je da sve skupine vremenskih neprilika nemaju 
distribuciju istog oblika (11), odnosno da postoji statistički značajna razlika među skupinama. Primjenom Kruskal-Wallis-ovog testa u Real Statistics-u, na razini značajnosti od $5 \%(\alpha=0,05)$ i postavljenim hipotezama (10 i 11), dobivamo rezultate da treba odbaciti nultu hipotezu, odnosno da postoji značajna razlika među skupinama vremenskih neprilika (podaci iz Tablice 5.: $p=0,0011946<0,05$ ili sig: yes).

$$
\begin{aligned}
& H_{0}: \mu_{1}=\mu_{2}=\mu_{3} \\
& H_{1}: \mu_{1} \neq \mu_{2} \quad \text { ili } \quad \mu_{1} \neq \mu_{3} \quad \text { ili } \quad \mu_{2} \neq \mu_{3}
\end{aligned}
$$

Tablica 5. Primjena Kruskal-Wallis-ovog testa u Real Statistics-u za testiranje različitosti među skupinama vremenskih neprilika

\begin{tabular}{|c|c|c|c|c|}
\hline & Oborine $\geq 10 \mathrm{~mm}$ & $\begin{array}{l}\text { Olujni } \\
\text { vjetar }\end{array}$ & \multicolumn{2}{|c|}{ Hladni dani $\mathrm{Tmin}<0^{\circ} \mathrm{C}$} \\
\hline median & 4 & 1 & 6 & \\
\hline rank sum & 1014 & 643,5 & 1192,5 & \\
\hline count & 25 & 25 & 25 & 75 \\
\hline$r^{\wedge} 2 / n$ & 41127,84 & 16563,69 & 56882,25 & 114573,78 \\
\hline H-stat & & & & 13,207958 \\
\hline H-ties & & & & 13,459925 \\
\hline df & & & & \\
\hline $\mathrm{p}$-value & & & & 0,0011946 \\
\hline alpha & & & & 0,05 \\
\hline sig & & & & yes \\
\hline
\end{tabular}

Kruskal-Wallis Test

Kako bi ustanovili koje se točno skupine vremenskih neprilika razlikuju, uspoređujemo svake dvije međusobno koristeći Mann-Whitney-jev test u Real Statistics-u i postavljamo nulte hipoteze da dvije međusobno uspoređivane skupine imaju distribuciju istog oblika (12). Alternativne hipoteze su da dvije međusobno uspoređivane skupine nemaju distribuciju istog oblika (13). S obzirom na broj skupina, provodimo tri post hoc testa (odnosno ukupno imamo tri para hipoteza $m$ ) pa je korigirana razina značajnosti (14) korištenjem Bonferroni-jeve korekcije (6).

$$
\begin{aligned}
& H_{0}: \mu_{1}=\mu_{2} \\
& H_{1}: \mu_{1} \neq \mu_{2} \\
& \alpha^{\prime}=\frac{\alpha}{m}=\frac{0,05}{3}=0,01667
\end{aligned}
$$


Tablica 6. Primjena Mann-Whitney-jeva testa u Real Statistics-u za mjesec siječanj međusobno uspoređujući Oborine ( $\geq 10 \mathrm{~mm}$ ) i Olujni vjetar

Mann-Whitney Test for Two Independent Samples

\begin{tabular}{l|rr}
\multicolumn{1}{c}{} & Oborine $\geq 10 \mathrm{~mm}$ & Olujni vjetar \\
\cline { 2 - 3 } count & 25 & 25 \\
median & 4 & 1 \\
rank sum & 778 & 497 \\
U & 172 & 453 \\
\cline { 2 - 3 } \multicolumn{1}{c}{} & \multicolumn{2}{c}{ one tail } \\
alpha & 0,01667 & two tail \\
U & 172 & \\
mean & 312,5 & \\
std dev & 50,9313764 & ties \\
Z-score & 2,758613843 & \\
effect r & 0,390126911 & \\
U-crit & 204,1198225 & 190,5750495 \\
p-value & 0,002902354 & 0,005804708 \\
sig (norm) & yes & yes \\
\cline { 2 - 3 } &
\end{tabular}

Tablica 7. Primjena Mann-Whitney-jeva testa u Real Statistics-u za mjesec siječanj međusobno uspoređujući Oborine $(\geq 10 \mathrm{~mm})$ i Hladne dane $\left(T_{\min }<0{ }^{\circ} \mathrm{C}\right)$

Mann-Whitney Test for Two Independent Samples

\begin{tabular}{l|rr}
\multicolumn{1}{c}{} & Oborine $\geq 10 \mathrm{~mm}$ Hladni dani Tmin $<0{ }^{\circ} \mathrm{C}$ \\
\cline { 2 - 3 } count & 25 & 25 \\
median & 4 & 6 \\
rank sum & 561 & 714 \\
$\mathrm{U}$ & 389 & 236 \\
\hline
\end{tabular}

\begin{tabular}{|c|c|c|}
\hline & one tail & two tail \\
\hline alpha & 0,01667 & \\
\hline $\mathrm{U}$ & 236 & \\
\hline mean & 312,5 & \\
\hline std dev & 51,17496997 ties & \\
\hline z-score & 1,49487142 & \\
\hline effect $r$ & 0,211406744 & \\
\hline U-crit & 203,6014639 & 189,9919093 \\
\hline p-value & 0,067474001 & 0,134948003 \\
\hline sig (norm) & no & no \\
\hline
\end{tabular}


Tablica 8. Primjena Mann-Whitney-jeva testa u Real Statistics-u za mjesec siječanj međusobno uspoređujući Olujni vjetar i Hladne dane $\left(T_{\min }<0{ }^{\circ} \mathrm{C}\right)$

Mann-Whitney Test for Two Independent Samples

\begin{tabular}{|c|c|c|}
\hline \multirow{5}{*}{$\begin{array}{l}\text { count } \\
\text { median } \\
\text { rank sum } \\
\text { U }\end{array}$} & Olujni vjetar & Hladni dani Tmin $<0{ }^{\circ} \mathrm{C}$ \\
\hline & 25 & 25 \\
\hline & 1 & 6 \\
\hline & 471,5 & 803,5 \\
\hline & 478,5 & 146,5 \\
\hline & one tail & two tail \\
\hline alpha & 0,01667 & \\
\hline $\mathrm{U}$ & 146,5 & \\
\hline mean & 312,5 & \\
\hline std dev & 50,75199805 & ties \\
\hline z-score & 3,270807187 & \\
\hline effect $r$ & 0,462561988 & \\
\hline U-crit & 204,5015333 & 191,0044645 \\
\hline p-value & 0,000536205 & 0,00107241 \\
\hline sig (norm) & yes & yes \\
\hline
\end{tabular}

Tablice 6.-8. prikazuju međusobne usporedbe vremenskih neprilika, primjenom Mann-Whitney-jeva testa, s korigiranom razinom značajnosti $\left(\alpha^{\prime}=0,01667\right)$ i postavljenim hipotezama (12 i 13). Razmatrajući kritično područje dvostranog testa - two tail (zbog odnosa jednakosti, odnosno nejednakosti postavljenih hipoteza), zaključujemo da su statistički značajne razlike između Oborina ( $\geq 10 \mathrm{~mm}$ ) i Olujnog vjetra (podaci iz Tablice 6. pod two tail: $p=0,005804708<0,01667$ ili sig (norm): yes) te statistički značajne razlike između Olujnog vjetra i Hladnih dana $\left(\mathrm{T}_{\min }<0{ }^{\circ} \mathrm{C}\right.$ ) (podaci iz Tablice 8. pod two tail: $p=0,00107241<0,01667$ ili sig (norm): yes).

S obzirom na podatke o broju dana s djelovanjem pojedine vremenske neprilike, za vremensko razdoblje od 25 godina te međusobno uspoređujući svake dvije vremenske neprilike i razmatrajući kritično područje dvostranog testa, uz sumiranje svih podataka o broju dana u mjesecu $\mathrm{s}$ djelovanjem pojedine vremenske neprilike kroz 25 godina za mjesec siječanj, zaključujemo da će Oborine $(\geq 10 \mathrm{~mm})$ i Hladni dani $\left(\mathrm{T}_{\min }<0{ }^{\circ} \mathrm{C}\right), \mathrm{u}$ odnosu na Olujni vjetar, značajno češće ometati izvođenje radova na gradilištu, odnosno Olujni vjetar će, u odnosu na sve tri testirane skupine, najmanje ometati izvođenje radova na gradilištu u mjesecu siječnju. 
Tablica 9. Sumarni zaključci s obzirom na vremenske neprilike

\begin{tabular}{|c|c|}
\hline \multicolumn{2}{|r|}{ ZAKLJUČCI } \\
\hline MJESECI & $\begin{array}{c}\text { MEĐUSOBNE USPOREDBE IZMEĐU OBORINA }(\geq 10 \mathrm{~mm}) \text {, } \\
\text { OLUJNOG VJETRA I HLADNIH DANA }\left(\mathrm{T}_{\min }<0^{\circ} \mathrm{C}\right)\end{array}$ \\
\hline Siječanj & $\begin{array}{l}\text { Oborine }(\geq 10 \mathrm{~mm}) \text { i Hladni dani }\left(\mathrm{T}_{\min }<0^{\circ} \mathrm{C}\right) \text { će značajno češće od } \\
\text { Olujnog vjetra ometati izvođenje radova. } \\
\text { Olujni vjetar će najmanje ometati izvođenje radova. }\end{array}$ \\
\hline $\begin{array}{l}\text { Veljača } \\
\text { Prosinac }\end{array}$ & $\begin{array}{l}\text { Oborine ( } \geq 10 \mathrm{~mm} \text { ) će značajno češće od Olujnog vjetra ometati } \\
\text { izvođenje radova. } \\
\text { Olujni vjetar će značajno manje od Oborina }(\geq 10 \mathrm{~mm} \text { ) ometati } \\
\text { izvođenje radova. } \\
\text { Statistički značajne razlike nema između djelovanja Oborina }(\geq 10 \\
\text { mm) i Hladnih dana }\left(\mathrm{T}_{\min }<0{ }^{\circ} \mathrm{C}\right) \text { te između djelovanja Olujnog } \\
\text { vjetra i Hladnih dana }\left(\mathrm{T}_{\min }<0^{\circ} \mathrm{C}\right) .\end{array}$ \\
\hline $\begin{array}{l}\text { Ožujak } \\
\text { Travanj } \\
\text { Studeni }\end{array}$ & $\begin{array}{l}\text { Oborine }(\geq 10 \mathrm{~mm}) \text { će najviše ometati izvođenje radova. } \\
\text { Hladni dani }\left(\mathrm{T}_{\min }<0^{\circ} \mathrm{C}\right) \text { i Olujni vjetar će značajno manje od } \\
\text { Oborina }(\geq 10 \mathrm{~mm}) \text { ometati izvođenje radova. }\end{array}$ \\
\hline Listopad & $\begin{array}{l}\text { Oborine }(\geq 10 \mathrm{~mm}) \text { će značajno češće od Olujnog vjetra, dok će } \\
\text { Olujni vjetar značajno češće od Hladnih dana }\left(\mathrm{Tmin}<0{ }^{\circ} \mathrm{C}\right) \text {, } \\
\text { ometati izvođenje radova. } \\
\text { Oborine }(\geq 10 \mathrm{~mm}) \text { će najviše ometati izvođenje radova. } \\
\text { Hladni dani }\left(\mathrm{T}_{\min }<0^{\circ} \mathrm{C}\right) \text { će najmanje ometati izvođenje radova. }\end{array}$ \\
\hline MJESECI & $\begin{array}{c}\text { MEĐUSOBNE USPOREDBE IZMEĐU OBORINA ( } \geq 10 \mathrm{~mm}) \text {, } \\
\left.\text { OLUJNOG VJETRA I VRUĆIH DANA ( } \mathrm{T}_{\max } \geq 30^{\circ} \mathrm{C}\right)\end{array}$ \\
\hline $\begin{array}{l}\text { Svibanj } \\
\text { Rujan }\end{array}$ & $\begin{array}{l}\text { Oborine ( } \geq 10 \mathrm{~mm} \text { ) će najviše ometati izvođenje radova. } \\
\text { Olujni vjetar i Vrući dani }\left(\mathrm{T}_{\max } \geq 30^{\circ} \mathrm{C}\right) \text { će značajno manje od } \\
\text { Oborina }(\geq 10 \mathrm{~mm} \text { ) ometati izvođenje radova. }\end{array}$ \\
\hline $\begin{array}{l}\text { Lipanj } \\
\text { Srpanj } \\
\text { Kolovoz }\end{array}$ & $\begin{array}{l}\text { Vrući dani }\left(\mathrm{T}_{\max } \geq 30^{\circ} \mathrm{C}\right) \text { će značajno češće od Oborina }(\geq 10 \mathrm{~mm}) \text {, } \\
\text { dok će Oborine }(\geq 10 \mathrm{~mm}) \text { značajno češće od Olujnog vjetra, } \\
\text { ometati izvođenje radova. } \\
\text { Vrući dani }\left(\mathrm{T}_{\max } \geq 30^{\circ} \mathrm{C}\right) \text { će najviše ometati izvođenje radova. } \\
\text { Olujni vjetar će najmanje ometati izvođenje radova. }\end{array}$ \\
\hline
\end{tabular}


Tablica 9. prikazuje sumarne zaključke primjenom Kruskal-Wallis-ovog i Mann-Whiteny-jevog testa za mjesece (od listopada do travnja) karakteristične sa zabilježenim djelovanjima Oborina $(\geq 10 \mathrm{~mm})$, Olujnog vjetra i Hladnih dana $\left(\mathrm{T}_{\min }<0{ }^{\circ} \mathrm{C}\right)$ te sumarne zaključke za mjesece (od svibnja do rujna) karakteristične sa zabilježenim djelovanjima Oborina ( $\geq$ $10 \mathrm{~mm})$, Olujnog vjetra i Vrućih dana $\left(\mathrm{T}_{\max } \geq 30^{\circ} \mathrm{C}\right)$.

\subsection{Intervalna procjena očekivanja u skupini $s$ normalnom distribucijom podataka}

Intervalna procjena očekivanja označava primjenu odgovarajućih statističkih testova koji, ovisno o veličini skupine te ovisno o poznatoj ili nepoznatoj vrijednosti varijance, kao i razini pouzdanosti $(1-\alpha)$, određuje raspon intervala s vjerodostojnom procjenom podataka unutar dobivenog intervala. Primjena intervalne procjene očekivanja prikladna je za testiranje male skupine $(n \leq 30)$ s normalom distribucijom podataka, kao i za testiranje velike skupine $(n>30)$ s podacima koji tada ne trebaju imati normalnu distribuciju.

Izraz za intervalnu procjenu očekivanja u maloj skupini $(n \leq 30) \mathrm{s}$ normalnom distribucijom podataka i nepoznatom varijancom je (15), gdje je $\bar{x}$ aritmetička sredina, $\frac{t_{\alpha}}{2}(n-1) \frac{\hat{s}}{\sqrt{n}}$ širina intervala, a $\hat{s}$ standardna devijacija [6]. Vrijednosti kvantila $t_{\frac{\alpha}{2}}(n-1)$ tražimo među kvantilima Studentove ili t-distribucije s $(n-1)$ stupnjeva slobode (df) $[6,8]$.

$$
\left\langle\bar{x}-t_{\frac{\alpha}{2}}(n-1) \frac{\hat{s}}{\sqrt{n}}, \bar{x}+t_{\frac{\alpha}{2}}(n-1) \frac{\hat{s}}{\sqrt{n}}\right\rangle
$$

2.2.1. Primjena intervalne procjene očekivanja u skupini s normalnom distribucijom podataka

Prethodno je istaknuto da vremenske neprilike predstavljaju nezavisne skupine jer svaka pojedina vremenska neprilika nije nužno i uvjet pojave neke druge vremenske neprilike. Međutim, u svrhu realne analize problematike mogućih dana zastoja pri radu gradilišta zbog vremenskih neprilika, možemo primijeniti princip uključivanja-isključivanja [9]. Princip uključivanja-isključivanja predstavlja matematičko očekivanje broja dana u mjesecu s barem jednom vremenskom neprilikom. Primjenom principa uključivanja-isključivanja, odnosno primjenom matematičkog očekivanja broja dana u mjesecu s barem jednom vremenskom neprilikom, ujedno dobivamo i matematičko očekivanje broja onih dana kada vremenske neprilike dovode do zastoja pri radu gradilišta. Prethodno razmatrajući dobivene podatke iz DMHZ-a i, na temelju tih podataka, strukturirajući tri karakteristične skupine vremenskih neprilika za svaki pojedini mjesec, 
izraz primjene principa uključivanja-isključivanja, odnosno izraz za matematičko očekivanje broja dana $u$ mjesecu $s$ barem jednom vremenskom neprilikom, tada bi glasio (16), gdje je $d$ broj dana u mjesecu, $a$ broj dana sa zabilježenim djelovanjem oborinama ( $\geq 10 \mathrm{~mm}$ ), $b$ broj dana sa zabilježenim djelovanjem olujnog vjetra i $c$ broj dana sa zabilježenim djelovanjem hladnih dana $\left(\mathrm{T}_{\min }<0{ }^{\circ} \mathrm{C}\right)$, odnosno vrućih dana $\left(\mathrm{T}_{\max } \geq 30{ }^{\circ} \mathrm{C}\right)$, ovisno o pojednom mjesecu. Nadalje, izrazi $\frac{a}{d} \cdot b, \frac{a}{d} \cdot c, \frac{b}{d} \cdot c$, predstavljaju matematičko očekivanje broja dana u mjesecu koji imaju zabilježeno djelovanje, redom, oborina ( $\geq 10 \mathrm{~mm}$ ) i olujnog vjetra, zatim oborina ( $\geq 10$ $\mathrm{mm})$ i hladnih $\left(\mathrm{T}_{\min }<0{ }^{\circ} \mathrm{C}\right)$, odnosno vrućih dana $\left(\mathrm{T}_{\max } \geq 30{ }^{\circ} \mathrm{C}\right)$ te naposljetku, olujnog vjetra i hladnih $\left(\mathrm{T}_{\min }<0{ }^{\circ} \mathrm{C}\right)$, odnosno vrućih dana $\left(\mathrm{T}_{\max }\right.$ $\geq 30{ }^{\circ} \mathrm{C}$ ). Izraz $\frac{a}{d} \cdot \frac{b}{d} \cdot c$ predstavlja matematičko očekivanje broja dana sa zabilježenim djelovanjem i oborina ( $\geq 10 \mathrm{~mm}$ ) i olujnog vjetra te hladnih $\left(\mathrm{T}_{\min }<0{ }^{\circ} \mathrm{C}\right)$, odnosno vrućih dana $\left(\mathrm{T}_{\max } \geq 30{ }^{\circ} \mathrm{C}\right)$, odnosno broj dana $\mathrm{u}$ mjesecu sa zabilježenim djelovanjem svih triju karakterističnih skupina vremenskih neprilika, ovisno o pojedinom mjesecu.

$$
a+b+c-\frac{a}{d} \cdot b-\frac{a}{d} \cdot c-\frac{b}{d} \cdot c+\frac{a}{d} \cdot \frac{b}{d} \cdot c
$$

Tablica 10. prikazuje primjenu principa uključivanja-isključivanja kroz izraz (16) za mjesec siječanj koji broji 31 dan $(d)$ i zabilježeno djelovanje Oborina $(\geq 10 \mathrm{~mm})(a)$, Olujnog vjetra $(b)$ i Hladnih dana $\left(\mathrm{T}_{\min }<0{ }^{\circ} \mathrm{C}\right)(c)$. Primjenom principa uključivanja-isključivanja, odnosno primjenom matematičkog očekivanja broja dana u mjesecu siječnju s barem jednom vremenskom neprilikom, ujedno dobivamo i matematičko očekivanje broja onih dana u mjesecu siječnju kada vremenske neprilike dovode do zastoja pri radu gradilišta za vremensko razdoblje od 25 godina (od 1992. do 2016.). Tako dobivenoj skupini testiramo distribuciju podataka u svrhu odgovarajuće daljnje primjene statističkih testova.

Testiranjem distribucije podataka skupine s matematički očekivanim brojevima dana zastoja pri radu gradilišta za mjesec siječanj za vremensko razdoblje od 25 godina, primjenom Shapiro-Wilk testa u Real Statistics-u, na razini značajnosti od $5 \%(\alpha=0,05)$, dobivamo rezultate da je zadovoljen uvjet normalne distribucije podataka. (Tablica 11.). S obzirom da je za dobivenu skupinu zadovoljen uvjet normalne distribucije podataka, možemo zaključiti da je prikladno koristiti intervalnu procjenu očekivanja $\mathrm{u}$ maloj skupini $(n \leq 30)$ s normalnom distribucijom podataka i nepoznatom varijancom. 
Tablica 10. Broj mogućih dana zastoja pri radu gradilišta za mjesec siječanj, ovisno o pojedinoj godini

\begin{tabular}{|c|c|c|c|c|c|}
\hline Rijeka & \multicolumn{4}{|c|}{ Pregled broja dana } & \multirow{2}{*}{\begin{tabular}{||c|} 
Matematičko \\
očekivanje \\
broja dana \\
zastoja pri radu \\
gradilišta zbog \\
vremenskih \\
neprilika \\
\end{tabular}} \\
\hline Siječanj & $\begin{array}{c}\text { Oborine } \geq \\
10 \mathrm{~mm}\end{array}$ & Olujni vjetar & $\begin{array}{l}\text { Hladni dani } \\
\mathrm{T}_{\min }<0{ }^{\circ} \mathrm{C}\end{array}$ & $\begin{array}{c}\text { Vrući dani } \\
\mathrm{T}_{\max } \geq 30^{\circ} \mathrm{C}\end{array}$ & \\
\hline 1992. & 1 & 1 & 6 & 0 & 7,59 \\
\hline 1993. & 0 & 3 & 8 & 0 & 10,23 \\
\hline 1994. & 4 & 1 & 1 & 0 & 5,71 \\
\hline 1995. & 6 & 3 & 9 & 0 & 14,98 \\
\hline 1996. & 5 & 1 & 6 & 0 & 10,71 \\
\hline 1997. & 8 & 1 & 0 & 0 & 8,74 \\
\hline 1998. & 2 & 4 & 5 & 0 & 9,82 \\
\hline 1999. & 4 & 2 & 2 & 0 & 7,37 \\
\hline 2000. & 0 & 1 & 9 & 0 & 9,71 \\
\hline 2001. & 7 & 5 & 4 & 0 & 13,47 \\
\hline 2002. & 1 & 1 & 8 & 0 & 9,46 \\
\hline 2003. & 4 & 7 & 8 & 0 & 15,49 \\
\hline 2004. & 5 & 3 & 10 & 0 & 15,09 \\
\hline 2005. & 1 & 7 & 7 & 0 & 13,02 \\
\hline 2006. & 3 & 3 & 10 & 0 & 13,87 \\
\hline 2007. & 5 & 1 & 1 & 0 & 6,65 \\
\hline 2008. & 6 & 0 & 1 & 0 & 6,81 \\
\hline 2009. & 7 & 1 & 9 & 0 & 14,52 \\
\hline 2010. & 8 & 0 & 8 & 0 & 13,94 \\
\hline 2011. & 2 & 4 & 5 & 0 & 9,82 \\
\hline 2012. & 2 & 0 & 8 & 0 & 9,48 \\
\hline 2013. & 6 & 3 & 2 & 0 & 9,88 \\
\hline 2014. & 8 & 2 & 1 & 0 & 10,18 \\
\hline 2015. & 4 & 1 & 1 & 0 & 5,71 \\
\hline 2016. & 6 & 1 & 6 & 0 & 11,49 \\
\hline
\end{tabular}


Tablica 11. Primjena Shapiro-Wilk testa u Real Statistics-u za skupinu s matematički očekivanim brojevima dana zastoja pri radu gradilišta za mjesec siječanj

Shapiro-Wilk Test

\begin{tabular}{lr} 
& $\begin{array}{c}\text { Matematičko očekivanje broja } \\
\text { dana zastoja pri radu gradilišta } \\
\text { zbog vremenskih neprilika }\end{array}$ \\
\hline W-stat & 0,938140034 \\
p-value & 0,134076634 \\
alpha & 0,05 \\
normal & yes \\
\hline
\end{tabular}

Izračunom standardne devijacije (naredba u Excel-u: „stdev.s") te $\mathrm{s}$ obzirom na broj podataka u skupini (naredba u Excel-u: „count“, odnosno za vremensko razdoblje od 25 godina) i razinom pouzdanosti od $95 \%$ (1 $\alpha=0,05$ ), možemo dobiti vrijednost širine intervala (naredba u Excel-u „confidence.t") za testiranu skupinu s matematički očekivanim brojevima dana zastoja pri radu gradilišta. Razina pouzdanosti od $95 \%$ znači da za 95 $\%$ slučajeva imamo odgovarajuću intervalnu procjenu, dok je za $5 \%$ slučajeva intervalna procjena pogrešna. Prema dobivenoj vrijednosti širine intervala dobivamo interval tako da za donju vrijednost intervala od aritmetičke sredine (naredba u Excel-u „average") oduzmemo širinu intervala, a za gornju vrijednost intervala aritmetičkoj sredini dodamo vrijednost širine interval (Tablica 12.). Interval s vrijednostima od 9,30 do 11,80 označava vjerodostojnu statističku procjenu skupine s matematički očekivanim brojevima dana zastoja pri radu gradilišta za mjesec siječanj. Odnosno, interpretacija tog intervala naglašava da je $95 \%$ sigurno da matematičko očekivanje broja onih dana kada vremenske neprilike dovode do zastoja pri radu gradilišta leži u intervalu od 9,30 do 11,80.

Tablica 12. Primjena intervalne procjene očekivanja u skupini s normalnom distribucijom podataka u Excel-u za mjesec siječanj

Aritmetička sredina (Mean)

Standardna devijacija (Standard Deviation)

Broj uzorka (Count)

Širina intervala

Interval
10,55

3,036613631

25

1,253452501

$<\quad 9,30$

$11,80>$

U Tablici 13. prikazani su mjesečni intervali s matematički očekivanim danima zastoja zbog vremenskih neprilika pri radu gradilišta. Budući da za mjesec lipanj na temelju postavljenih pretpostavki nije dobivena skupina s 
normalnom distribucijom podataka, kao mjerodavna veličina uzet će se medijan testirane skupine. Ljetni mjeseci na području grada Rijeke imaju najveći broj matematički očekivanih dana zastoja zbog velikog broja dana s izrazito visokim vrućinama, dok proljetni mjeseci imaju najmanji broj matematički očekivanih dana zastoja pri radu gradilišta zbog vremenskih neprilika.

Tablica 13. Mjesečni intervali s matematički očekivanim danima zastoja

\begin{tabular}{|c|c|c|c||}
\hline \multicolumn{4}{|c|}{ ZAKLJUČCI } \\
\hline \hline \multicolumn{3}{||}{$\begin{array}{l}\text { MJESEČNI INTERVALI S MATEMATIČKI OČEKIVANIM DANIMA ZASTOJA } \\
\text { PRI RADU GRADILIŠTA ZBOG VREMENSKIH NEPRILIKA [dani] }\end{array}$} \\
\hline \hline Siječanj & $\langle 9,30-11,80\rangle$ & Srpanj & $\langle 14,23-19,33\rangle$ \\
\hline Veljača & $\langle 7,67-11,33\rangle$ & Kolovoz & $\langle 14,09-19,15\rangle$ \\
\hline Ožujak & $\langle 4,31-6,81\rangle$ & Rujan & $\langle 6,05-8,01\rangle$ \\
\hline Travanj & $\langle 2,91-4,87\rangle$ & Listopad & $\langle 4,97-7,40\rangle$ \\
\hline Svibanj & \multicolumn{1}{|c|}{$\langle 3,22-5,29\rangle$} & Studeni & $\langle 6,61-8,94\rangle$ \\
\hline Lipanj & $\begin{array}{l}\text { Podaci nemaju } \\
\text { normalnu distribuciju! } \\
\text { Medijan ima vrijednost } \\
7,6 .\end{array}$ & Prosinac & $\langle 7,19-10,86\rangle$ \\
\hline
\end{tabular}

Dobiveni mjesečni intervali s matematički očekivanim danima zastoja pri radu gradilišta zbog vremenskih neprilika rezultati su primjene matematičke i statističke obrade podataka te imaju kvantitativnu i izvjesnu vrijednost. Također, pokazatelj su potrebnih rezervi koje je potrebno uzeti u obzir prilikom, ponajprije i najvažnije, definiranja vremenskog roka za građenje i, unutar tog roka, ključnih međurokova građenja. Prilikom definiranja vremenskog roka za građenje, mjesečni intervali bi služili kao nadodana gruba vremenska rezerva za očekivane zastoje pri radu gradilišta zbog vremenskih neprilika, ovisno o mjesecima kroz koje se planira izvođenje radova. Detaljiziranjem vremenskog plana prilikom izrade ponude za građenje te daljnjim detaljiziranjem plana prilikom samog građenja, potrebno je ažuriranje i nadograđivanje vremenskog plana, primjerice, na mjesečnoj bazi. Mjesečni intervali s matematički očekivanim danima zastoja pri radu gradilišta zbog vremenskih neprilika posebno pogoduju mjesečnom ažuriranju vremenskog plana gdje bi se, unutar jednog mjeseca, moglo odgovarajuće isplanirati izvršenje svih onih aktivnosti, čija uspješna realizacija u značajnoj mjeri ovisi upravo o povoljnim vremenskim uvjetima. Vremenski plan je podloga za praćenje i kontrolu izvođenja radova [10]. Na temelju praćenja i kontrole plana mogu 
se pravovremeno donijeti ispravne odluke i odgovarajuće korektivne mjere. Vremensko planiranje podrazumijeva kontinuirano ažuriranje, detaljiziranje i poboljšanje vremenskog plana te praćenje i kontrolu izvršenja planiranih aktivnosti u svrhu smanjivanja neizvjesnosti prilikom izvođenja radova na gradilištu. Pri tome, mjesečni intervali s matematički očekivanim danima zastoja zbog vremenskih neprilika mogu imati značajnu ulogu.

\section{Zaključak}

Kontinuirani i zadovoljavajući tijek izvođenja radova na gradilištu u zavisnom je odnosu s vremenskim utjecajima. Zanemarivanje vremenskog utjecaja jedan je od uzroka prekoračenja vremenskog roka za građenje. S tim u vezi, rad daje rezultate statističke obrade podataka pri testiranju različitosti utjecaja vremenskih neprilika prilikom građenja te statističku intervalnu kvantifikaciju matematički očekivanih dana zastoja pri radu gradilišta zbog nepovoljnih vremenskih uvjeta na području grada Rijeke. Detaljna statistička obrada prikazana je samo za mjesec siječanj, dok su statistički rezultati za ostale mjesece prikazani kroz sumarne zaključke. Dobiveni mjesečni intervali, prikazani u radu, s matematički očekivanim danima zastoja pri radu gradilišta zbog vremenskih neprilika, predstavljaju vrijedan ulazni parametar u svrhu preciznije izrade vremenskog plana i definiranja roka za građenje na području grada Rijeke. Precizniji vremenski plan i rok za građenje rezultirao bi smanjenjem sadašnje problematike zastoja, kašnjenja i gubitaka na gradilištu kao i smanjenjem rada radnika pri nepovoljnim uvjetima i/ili prekovremenim radnim satima.

\section{Literatura}

[1] Ballesteros-Pérez, P., Rojas-Céspedes, Y.A., Hughes, W., Kabiri, S., Pellicer, E., Mora-Melià, D. and del Campo-Hitschfeld, M.L. (2017.) Weather-Wise: A Weather-Aware Planning Tool for Improving Construction Productivity and Dealing with Claims. Automation in Construction, 84, str. 81-95.

[2] Radujković, M. (1999.) Izvor prekoračenja rokova i proračuna građevinskih projekata. Građevinar, 51(2), str. 159-165.

[3] Moselhi, O., Gong, D. and El-Rayes, K. (1997.) Estimating Weather Impact on the Duration of Construction Activities. Canadian Journal of Civil Engineering, 24(3), str. 359-366.

[4] Wackerly, D.D, Mendenhall, W. III and Scheaffer, R.L., (2008.) Mathematical Statistics with Applications. Seventh Edition. Belmont, CA, USA: Thomson Learning, Inc.

[5] Thompson, C.M. (1941.) Table of Percentage Points of the $\chi 2$ Distribution. Biometrika, 32(2), str. 187-191. 
[6] Filipin, A. (ak. g. 2017./2018.) Nastavni materijali na kolegiju Primijenjena statistika, poslijediplomski doktorski studij, Građevinski fakultet, Sveučilište u Zagrebu.

[7] Walpole, R.E. (1968.) Introduction to Statistics. New York: Macmillan.

[8] Merrington, M. (1942.) Table of Percentage Points of the t-Distribution. Biometrika, 32(3-4), str. 300-300.

[9] Lipschutz, S., Lipson, M. (2000.) Probability. Schaum's Outlines. Second Edition. New York: McGraw-Hill.

[10] Radujković, M. i suradnici (2012.) Planiranje i kontrola projekata. Zagreb: Sveučilište u Zagrebu, Građevinski fakultet. 